\title{
Lymphoma cells with increased anti-oxidant defenses acquire chemoresistance
}

\author{
MARGARET E. TOME ${ }^{1}$, JENNIFER B. FRYE ${ }^{1}$, DONNA L. COYLE ${ }^{2,4}$, ELAINE L. JACOBSON ${ }^{2,3}$, \\ BETTY K. SAMULITIS ${ }^{4}$, KATERINA DVORAK ${ }^{3}$, ROBERT T. DORR ${ }^{4}$ and MARGARET M. BRIEHL ${ }^{1}$ \\ Departments of ${ }^{1}$ Pathology, ${ }^{2}$ Pharmacology and Toxicology, and ${ }^{3}$ Cell Biology and Anatomy; \\ ${ }^{4}$ Arizona Cancer Center, University of Arizona, Tucson, AZ 85724, USA
}

Received December 22, 2011; Accepted January 20, 2012

DOI: $10.3892 /$ etm.2012.487

\begin{abstract}
Chronic inflammation increases lymphoma risk. Chronic inflammation exposes cells to increased reactive oxygen species (ROS). Constant exposure to ROS selects for oxidative stress-resistant cells with upregulated anti-oxidant defense enzymes. The impact of oxidative stress resistance on the redox biology and chemotherapy response in lymphoma has not been rigorously tested. To measure the effect of antioxidant defense enzyme upregulation in lymphoid cells, we created oxidative stress-resistant WEHI7.2 thymic lymphoma cell variants. We selected a population of WEHI7.2 cells for resistance to hydrogen peroxide and constructed catalaseoverexpressing WEHI7.2 transfectants. The WEHI7.2 variants had: i) increased catalase and total superoxide dismutase activities; ii) an altered GSSG/2GSH redox potential; iii) a more oxidized $\mathrm{NADP}^{+} / \mathrm{NADPH}$ pool; and iv) increased phase 2 enzymes, NAD(P)H:quinone oxidoreductase and glutathione $S$-transferases $\mu$ and $\pi$. Regression analysis showed a correlation between the GSSG/2GSH redox potential and the increased phase 2 enzyme activities. As predicted from the anti-oxidant defense enzyme profile, the variants were more
\end{abstract}

Correspondence to: Dr Margaret E. Tome, Department of Pathology, University of Arizona, P.O. Box 245043, Tucson, AZ 85724, USA

E-mail:mtome@u.arizona.edu

Abbreviations: $200 \mathrm{R}$, WEHI7.2 cells selected for resistance to $200 \mu \mathrm{M}$ $\mathrm{H}_{2} \mathrm{O}_{2}$; CAT2, WEHI7.2 cells expressing 2-fold parental cell catalase; CAT38, WEHI7.2 cells expressing 1.4-fold parental cell catalase; cDCFH-DA/cDCFH, 5-(and-6)-carboxy-2'7'dichlorofluorescein diacetate; DCFH-DA/DCF, 2'7'dichlorodihydrofluorescein diacetate/ 2'7'dichlorofluorescein; DPIP, 2,6-dichlorophenol-indophenol; $\mathrm{E}_{\mathrm{h}}$, redox potential; G6PDH, glucose 6-phosphate dehydrogenase; GPX1, glutathione peroxidase 1; GSH, glutathione; GSSG, glutathione disulfide; GST, glutathione S-transferase; $\mathrm{H}_{2} \mathrm{O}_{2}$, hydrogen peroxide; JNK1, c-Jun N-terminal kinase; NQO1, NAD(P) $\mathrm{H}$ :quinone oxidoreductase, DT-diaphorase; $\mathrm{O}_{2}{ }^{\circ-}$, superoxide; PBS, phosphate-buffered saline; ROS, reactive oxygen species; SOD, superoxide dismutase

Key words: lymphoma, catalase, reactive oxygen species resistant to the oxidants hydrogen peroxide and paraquat. The variants exhibited resistance to the common lymphoma chemotherapeutics, cyclophosphamide, doxorubicin, vincristine and glucocorticoids. These data indicate that chronic ROS exposure results in lymphoid cells with multiple changes in their redox biology and a chemoresistance phenotype. These data further suggest that lymphomas that arise at the site of chronic inflammation develop chemoresistance due to a combination of drug detoxification and removal of ROS.

\section{Introduction}

Chronic infectious disease and inflammation increase lymphoma risk (1). Certain infectious agents are connected to specific types of lymphoma, including Helicobacter pylori in MALT lymphoma and human T-cell leukemia virus in adult T-cell leukemia/lymphoma (2). Several types of chronic infection, for example those caused by hepatitis $\mathrm{C}$ and Epstein-Barr virus, are a risk factor for multiple types of hematologic malignancies $(3,4)$. Although the connection between chronic inflammation and increased lymphoma risk is well established, how chronic inflammation contributes to lymphoma etiology and affects the response to chemotherapeutic intervention is not well understood.

One factor that cells at the site of chronic inflammation encounter is an increase in reactive oxygen species (ROS) as the host mounts an immune response. Infection of lymphoid cells with Epstein-Barr virus also directly increases intracellular ROS (5). Chronic exposure to ROS results in cells with increased anti-oxidant defense enzymes that allow cells to survive under these conditions (6-8). The impact of oxidative stress resistance on lymphoma chemotherapy response is unknown. To test the consequences of chronic ROS exposure on lymphoma drug response, we selected a population of WEHI7.2 murine thymic lymphoma cells resistant to hydrogen peroxide $\left(\mathrm{H}_{2} \mathrm{O}_{2}\right)(8)$, one of the ROS found at inflammatory sites. We also constructed WEHI7.2 transfectants that overexpress catalase (9), an enzyme that detoxifies $\mathrm{H}_{2} \mathrm{O}_{2}$, as proof of principle. Previously, we found that the oxidative stress resistant cells were cross-resistant to glucocorticoids, a commonly used lymphoma chemotherapeutic $(8,9)$.

Our hypothesis is that an alteration in anti-oxidant defense enzymes (or development of resistance to oxidants) results in 
multiple redox changes that contribute to chemoresistance. We predict that the oxidative stress-resistant cells will be resistant to agents that depend on ROS generation to cause death. However, we also expect cross-resistance to agents that do not depend on ROS per se, but are detoxified via pathways that respond to redox regulation. To test this hypothesis, we first measured primary anti-oxidant defense enzymes, small-molecule reductants and the phase 2 detoxification enzymes in the variants to assess the impact of anti-oxidant defense enzyme modulation on the redox biology of lymphoid cells. We then evaluated the response to chemotherapeutic drugs. These data indicate that: i) modulation of one anti-oxidant defense enzyme alters a web of redox responsive pathways in the cell; and ii) oxidative stress resistance potentially contributes to the chemoresistant phenotype in lymphoma.

\section{Materials and methods}

Drugs and chemicals. 4-Hydroxynonenol was purchased from Cayman Chemical Co. (Ann Arbor, MI, USA). All other drugs, chemicals and purified enzymes were purchased from Sigma Chemical Co. (St. Louis, MO, USA), except as noted.

Cell culture and development of variants. The mouse thymic lymphoma WEHI7.2 parental cell line (10) and variants overexpressing rat catalase (CAT2, 2-fold increase; CAT38, 1.4-fold increase), vector only (Neo2, Neo3) (9) or selected for resistance to $200 \mu \mathrm{M} \mathrm{H}_{2} \mathrm{O}_{2}$ (200R) (8), were maintained in suspension cultures, as described in the indicated references. Any variant normally grown in the presence of drug was cultured in the absence of drug for 1 week prior to each experiment. For all measurements, except $\mathrm{EC}_{50}$ and $\mathrm{EC}_{90}$, cells were subcultured in new medium $24 \mathrm{~h}$ before the samples were taken.

Protein measurements. Cellular protein was measured in clarified lysates using the BCA Protein Assay kit (Pierce, Rockford, IL, USA) according to the manufacturer's instructions.

Enzyme activity measurements. Prior to enzyme activity measurements, cells were washed twice with phosphatebuffered saline (PBS) at $4^{\circ} \mathrm{C}$. For the measurement of catalase, glutathione peroxidase, glutathione reductase and NAD $(\mathrm{P})$ $\mathrm{H}$ :quinone oxidoreductase (NQO1), cells were resuspended in $10 \mathrm{mM}$ Tris- $\mathrm{HCl}$, pH 7.5, $250 \mathrm{mM}$ sucrose, $1 \mathrm{mM}$ EDTA, $0.5 \mathrm{mM}$ dithiothreitol, $0.1 \mathrm{mM}$ phenylmethylsulfonyl fluoride and $1 \%$ Triton $\mathrm{X}-100$. Samples were incubated for $30 \mathrm{~min}$ at $4^{\circ} \mathrm{C}$ and centrifuged at $10,000 \mathrm{x}$ g for $15 \mathrm{~min}$ at $4^{\circ} \mathrm{C}$. Activity was measured in the supernatant fractions. Catalase and glutathione peroxidase activities were measured as described in Tome and Briehl (8). Glutathione reductase activity was measured in the supernatant by monitoring the disappearance of NADPH in the presence of glutathione disulfide (GSSG) (11). Activity was calculated using an extinction coefficient of $6.36 .3 \mathrm{mM}^{-1} \mathrm{~cm}^{-1}$. NQO1 activity was measured as the rate of 2,6-dichlorophenol-indophenol (DPIP) reduction (12). Rates were calculated using the extinction coefficient $2.1 \times 10^{4} \mathrm{M}^{-1} \mathrm{~cm}^{-1}$. The difference in rates in the presence and absence of dicumerol, which corrects for non-specific NAD $(P)$ $\mathrm{H}$ oxidase activity, was used to calculate specific NQO1 activity. Total superoxide dismutase (SOD) and glutathione S-transferase (GST) activities were measured as described in Tome and Briehl (8). Enzyme activities were normalized to cell protein. Glucose 6-phosphate dehydrogenase (G6PDH) activity was measured as in Tome et al (13). Enzyme activity was normalized to cell number.

Northern blots. Peroxiredoxin 1-3 expression was measured by northern blotting as previously described (8).

$E C_{50}$ and $E C_{90}$ measurements. Cells were grown in a range of drug or oxidant concentrations for $48 \mathrm{~h}$. For $\mathrm{H}_{2} \mathrm{O}_{2}$, relative cell number was measured using the Cell Proliferation kit II (XTT) (Roche Diagnostics, Mannheim, Germany) according to the manufacturer's protocol. For all other drugs and oxidants, relative cell number was measured using the Non-radioactive Cell Proliferation Assay (MTS) according to the manufacturer's protocol (Promega Corp., Madison, WI, USA). For both types of assays, the plates were read at $490 \mathrm{~nm}$ using a Microplate Autoreader (Bio-Tek Instruments). Fraction control absorbance was calculated as previously described (14). The $\mathrm{EC}_{50}$ or $\mathrm{EC}_{90}$ was defined as the concentration at which the absorbance was 50 or $90 \%$ that of the control, respectively. For each cell variant, at least three independent plates were assayed.

Apoptosis measurements. Sensitivity to dexamethasone was determined by incubating cells in a final concentration of $1 \mu \mathrm{M}$ dexamethasone in an ethanol vehicle (final concentration of ethanol $=0.01 \%$ ) or an equivalent amount of vehicle alone. Apoptotic cells were measured by flow cytometry as in Tome et al (15). The percentage of apoptotic cells in the presence of dexamethasone was corrected for that in the vehicle-treated cells for each cell variant.

Glutathione (GSH), glutathione disulfide and pyridine nucleotide measurements. GSH and GSSG were measured as dansyl derivatives using an HPLC with fluorometric detection as described by Jones et al (16), or using the Bioxytech GSH/ GSSG 412 kit (Oxis Research, Portland, OR, USA) according to the manufacturer's protocol. Pyridine nucleotides were extracted and measured using the enzymatic cycling method of Jacobson and Jacobson (17), which depends on the oxidation of thiazolyl blue. All measurements were normalized to cellular protein. Cell volume was calculated using the cell diameter measured with the Vi-Cell 1.01 (Beckman Coulter, Fullerton, CA, USA). Redox potential was calculated using a simplified Nernst equation $\mathrm{E}_{\mathrm{h}}(\mathrm{in} \mathrm{mV})=\mathrm{E}_{0}+30 \log [(\mathrm{GSSG}) /$ $\left.(\mathrm{GSH})^{2}\right]$ using molar concentrations of GSH and GSSG and $\mathrm{E}_{0}$ $=-264 \mathrm{mV}$ for $\mathrm{pH} 7.4(18)$.

ROS measurements. ROS was measured as in Tome et al (15) using the fluorescent dyes 5-(and-6)-carboxy2'7'dichlorofluorescein diacetate (cDCFH-DA/cDCFH) (C-369), 2'7'dichlorodihydrofluorescein diacetate (DCFH-DA/ DCF)(D-399) (Molecular Probes, Inc., Eugene, OR, USA) and propidium iodide. Cells that were propidium iodide-positive were excluded from analysis. Fluorescence due to DCF, which indicates ROS, was corrected for the relative cDCFH fluorescence to account for differences in dye uptake between the variants and the WEHI7.2 cells. 
Immunoblots. Proteins were separated by gel electrophoresis and blots were prepared as previously described (9). Blots were probed as previously described (9) using primary antibodies as follows: 1:7,500 dilution anti- $\mathrm{Cu}, \mathrm{ZnSOD}$ (Abcam Inc., Cambridge, MA, USA); 1:2,000 dilution anti-MnSOD (19); 1:2,000 dilution anti-GPX-1 (Lab Frontiers, Seoul, Korea); 1:500 dilution anti-GST Yb1 (GST $\mu$ ) and GST $\alpha$ (Biotrin, Dublin, Ireland); 1:1,000 dilution anti-GST $\pi$ (Biotrin); or $1: 10,000$ anti- $\beta$-actin (Abcam). Proteins were detected by incubating with a 1:2,000 dilution of horseradish peroxidase-linked anti-rabbit or anti-mouse Ig (GE Healthcare, Piscataway, NJ, USA) as appropriate, and visualized using chemiluminescence reagents as previously described (9).

Statistics. Means were compared by t-tests using the algorithms in Excel (Microsoft Corp., Redmond, WA, USA) or the formulas from Moore and McCabe (20). When a comparison required multiple t-tests, the Dunn-Bonferoni method was used to control for type I error (21). Correlation between variables was analyzed using the regression algorithm in Excel (Microsoft Corp.).

\section{Results}

Primary anti-oxidant defense enzyme activity. To fully characterize the redox biology in the WEHI7.2 cells and WEHI7.2 variants, we first quantified the primary antioxidant defense enzymes (Table I). In mammalian cells, the primary anti-oxidant defense enzymes metabolize $\mathrm{H}_{2} \mathrm{O}_{2}$ and superoxide $\left(\mathrm{O}_{2}{ }^{-}\right)$. For detoxifying $\mathrm{H}_{2} \mathrm{O}_{2}$, cells depend on catalase, glutathione peroxidase and peroxiredoxins. In exponentially growing cells, as shown in Table I, catalase activity was increased by approximately 2 -fold in the CAT2 catalase transfectants and by approximately 1.4 -fold in the CAT38 cells (9). The 200R cells, which are selected for growth in $200 \mu \mathrm{M}$ $\mathrm{H}_{2} \mathrm{O}_{2}$, also had approximately 1.4-fold the parental cell catalase activity (8). The vector only-overexpressing cells (Neo2, Neo3) had catalase activity similar to that in the WEHI7.2 cells. Glutathione peroxidase 1 (GPX1) protein was similar in the WEHI7.2 and WEHI7.2 variant cells (Fig. 1A). Although GPX1 protein was detectable by immunoblotting, activity was not detectable using either cumene hydroperoxide or $\mathrm{H}_{2} \mathrm{O}_{2}$ as substrates. There was no difference in the expression of peroxiredoxins 1-3 (data not shown).

Superoxide is metabolized by superoxide dismutase (SOD). $\mathrm{MnSOD}$ is located in the mitochondrial matrix and $\mathrm{Cu}, \mathrm{ZnSOD}$ is located in the cytosol and mitochondrial intermembrane space. Total SOD activity was increased in all the variants compared to the WEHI7.2, Neo2 and Neo3 cells (Table I). Elevated $\mathrm{Cu}, \mathrm{ZnSOD}$ protein was noted in the cells with higher total SOD activity, while MnSOD protein remained similar to that in the WEHI7.2 cells (Fig. 1B). This suggests that the increased SOD activity was likely due to an increase in $\mathrm{Cu}, \mathrm{ZnSOD}$.

Increasing catalase modulates small-molecule reductants and the redox environment. Small-molecule reductants, including GSH and NADPH, contribute to the ability of the anti-oxidant defense enzymes to detoxify ROS. Ratios of the oxidized and
Table I. Primary anti-oxidant defense enzyme activities in the WEHI7.2 cells and WEHI7.2 variants.

\begin{tabular}{lcc}
\hline Cell variant & $\begin{array}{c}\text { Catalase } \\
\left(\mu \mathrm{mol} \mathrm{H}_{2} \mathrm{O}_{2} /\right. \\
\text { min/mg prot })\end{array}$ & $\begin{array}{c}\text { Superoxide } \\
\text { dismutase } \\
(\mathrm{U} / \mathrm{mg} \text { prot })\end{array}$ \\
\hline WEHI7.2 & $14.64 \pm 0.28$ & $10.6 \pm 0.4$ \\
Neo2 & $13.10 \pm 0.93$ & $8.4 \pm 0.6$ \\
Neo3 & $13.57 \pm 1.53$ & $8.7 \pm 1.1$ \\
CAT2 & $27.19 \pm 0.73^{\mathrm{a}}$ & $18.9 \pm 0.7^{\mathrm{a}}$ \\
CAT38 & $19.27 \pm 0.22^{\mathrm{a}, \mathrm{b}}$ & $18.0 \pm 0.7^{\mathrm{a}}$ \\
200R & $19.94 \pm 0.22^{\mathrm{a}}$ & $18.8 \pm 0.6^{\mathrm{a}}$ \\
\hline
\end{tabular}

Values represent the means \pm SEM $(n=6)$. ${ }^{\text {aSignificantly different }}$ from WEHI7.2 values $(\mathrm{p} \leq 0.05)$ after controlling for type I error. ${ }^{\mathrm{b}} \mathrm{CAT} 38$ are significantly different from CAT2 values $(\mathrm{p} \leq 0.05)$.

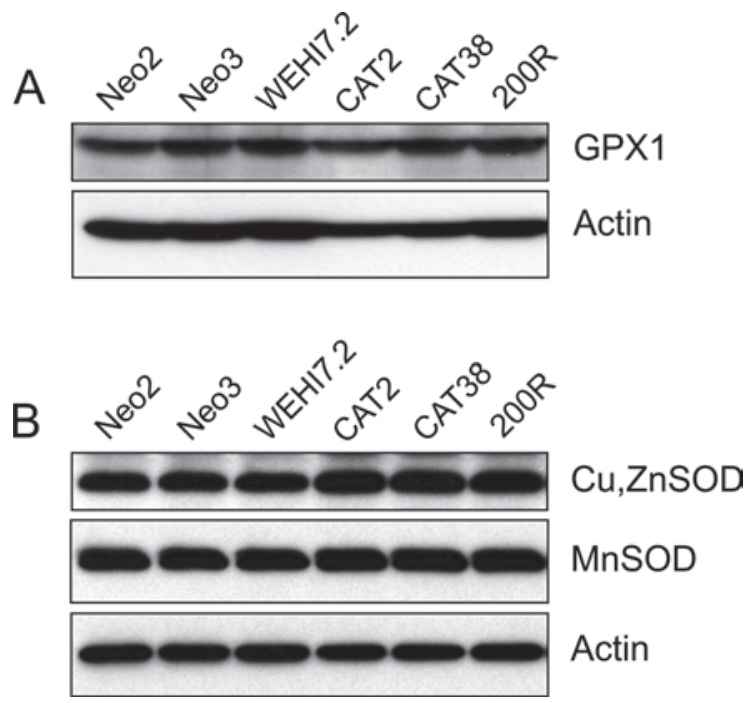

Figure 1. Analysis of anti-oxidant defense enzyme proteins in the WEHI7.2 cells and WEHI7.2 variants. (A) Immunoblots of whole cell lysates from parental WEHI7.2, vector only-transfected (Neo2, Neo3), catalase-transfected (CAT2, CAT38) and $\mathrm{H}_{2} \mathrm{O}_{2}$-resistant (200R) cells probed for GPX1. (B) Immunoblots probed for MnSOD and $\mathrm{Cu}, \mathrm{ZnSOD}$. Actin was included as a loading control. These are representative blots that have been replicated.

reduced forms of these molecules, in particular GSH, are also used to assess the intracellular redox environment $(18,22,23)$. To determine whether the WEHI7.2 variants had alterations in small-molecule reductants and the redox environment, we measured the status of the GSSG/GSH and NADP + NADPH redox couples. As shown in Table II, the amount of GSH per milligram protein was decreased in the CAT2, CAT38 and 200R cells. These differences were more pronounced when the molarity of GSH in the WEHI7.2 variants was calculated (Table II). There was no difference in the amount of GSSG. As an indication of the ability of the cells to reduce GSSG to GSH, we also measured glutathione reductase. Glutathione reductase activity was similar in all the cells.

To examine the redox state of the glutathione disulfideglutathione redox couple, we first calculated the GSH/GSSG ratio. Only slight differences in the GSH/GSSG ratio were 
Table II. Glutathione (GSH)/glutathione disulfide (GSSG) redox couple in the WEHI7.2 cells and WEHI7.2 variants.

\begin{tabular}{lcccccc}
\hline $\begin{array}{l}\text { Cell } \\
\text { variant }\end{array}$ & $\begin{array}{c}\text { GSH } \\
(\mathrm{nmol} / \mathrm{mg} \text { prot })\end{array}$ & $\begin{array}{c}\mathrm{GSH} \\
(\mathrm{mM})\end{array}$ & $\begin{array}{c}\text { GSSG } \\
(\mathrm{nmol} / \mathrm{mg} \text { prot })\end{array}$ & $\begin{array}{c}\text { Glutathione reductase } \\
(\mu \text { mol NADPH/ } \\
\mathrm{min} / \mathrm{mg} \text { prot })\end{array}$ & GSH/GSSG & $\begin{array}{c}\mathrm{E}_{\mathrm{h}} \\
(\mathrm{mV})\end{array}$ \\
\hline WEHI7.2 & $80.56 \pm 1.60$ & $7.05 \pm 0.28$ & $1.48 \pm 0.13$ & $44.3 \pm 0.8$ & $57.82 \pm 5.40$ & $-251.88 \pm 1.35$ \\
CAT2 & $64.03 \pm 2.12^{\mathrm{a}}$ & $4.14 \pm 0.22^{\mathrm{a}}$ & $1.34 \pm 0.13$ & $44.8 \pm 0.7$ & $50.36 \pm 4.31$ & $-243.18 \pm 1.13^{\mathrm{a}}$ \\
CAT38 & $61.74 \pm 2.88^{\mathrm{a}}$ & $4.60 \pm 0.35^{\mathrm{a}}$ & $1.24 \pm 0.14$ & $46.4 \pm 4.3$ & $54.19 \pm 6.10$ & $-245.24 \pm 1.70^{\mathrm{a}}$ \\
200R & $75.61 \pm 2.42$ & $5.24 \pm 0.27^{\mathrm{a}}$ & $1.64 \pm 0.23$ & $35.7 \pm 0.6$ & $51.72 \pm 5.88$ & $-246.33 \pm 1.12^{\mathrm{a}}$ \\
\hline
\end{tabular}

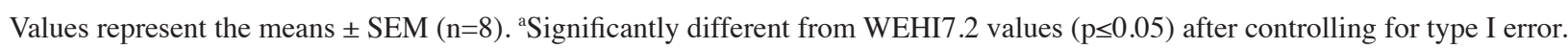

Table III. NADP + NADPH redox couple in the WEHI7.2 cells and WEHI7.2 variants.

\begin{tabular}{|c|c|c|c|c|}
\hline $\begin{array}{l}\text { Cell } \\
\text { variant }\end{array}$ & $\begin{array}{c}\text { NADPH } \\
(\mathrm{pmol} / \mathrm{mg} \text { prot })^{\mathrm{a}}\end{array}$ & $\begin{array}{l}\text { NADP }(\mathrm{H}) \text { total } \\
(\mathrm{pmol} / \mathrm{mg} \text { prot })^{\mathrm{a}}\end{array}$ & $\%$ reduced & $\begin{array}{c}\text { Glucose } 6 \text {-phosphate } \\
\text { dehydrogenase activity } \\
\left(\mathrm{nmol} \mathrm{TNBT} / 10^{6} \text { cells } / \mathrm{min}\right)^{\mathrm{b}}\end{array}$ \\
\hline WEHI7.2 & $53 \pm 8$ & $58 \pm 4$ & $91 \pm 14$ & $178.72 \pm 9.04$ \\
\hline CAT2 & $46 \pm 5$ & $72 \pm 6^{c}$ & $64 \pm 12$ & $229.29 \pm 10.88^{c}$ \\
\hline CAT38 & $27 \pm 4^{\mathrm{c}, \mathrm{d}}$ & $83 \pm 4^{c}$ & $33 \pm 9^{\mathrm{c}, \mathrm{d}}$ & $249.07 \pm 10.73^{c}$ \\
\hline $200 \mathrm{R}$ & $38 \pm 6$ & $67 \pm 4$ & $57 \pm 9^{c}$ & $265.45 \pm 16.13^{c}$ \\
\hline
\end{tabular}

${ }^{a}$ Values represent the means \pm SEM $(n=6)$. ${ }^{b}$ Values represent the means \pm SEM $(n=10)$. ${ }^{c}$ Significantly different from WEHI7.2 values $(p \leq 0.05)$ after controlling for type I error. ${ }^{\mathrm{d}} \mathrm{CAT} 38$ values are significantly different from CAT2 values $(\mathrm{p} \leq 0.05)$.

noted (Table II). However, since two molecules of GSH are required to form one molecule of GSSG, using the Nernst equation to calculate a redox potential is a better indicator of the redox environment $(22,23)$. When we calculated the redox potential $\left(\mathrm{E}_{\mathrm{h}}\right)$ of GSSG/2GSH, we found that the $\mathrm{E}_{\mathrm{h}}$ was higher in the CAT2, CAT38 and 200R cells $(\mathrm{p} \leq 0.05)$ than in the parental cells indicating a more oxidized redox environment in these variants (Table II). The $\mathrm{E}_{\mathrm{h}}$ in the vector only-transfected cells was similar to that in the WEHI7.2 cells $(0.97 \mathrm{mV}$ more reduced and $1.49 \mathrm{mV}$ more oxidized for the $\mathrm{Neo} 2$ and $\mathrm{Neo} 3$ cells, respectively).

The ultimate source of reducing equivalents to recycle GSSG is NADPH (22). Catalase also binds NADPH, although this does not seem to be required for activity (24). Bound NADPH eventually becomes oxidized and is replaced by a new molecule of NADPH (24). Cells with more catalase may use more NADPH. This suggests that the $\mathrm{NADP}^{+} / \mathrm{NADPH}$ redox couple may be critical in the WEHI7.2 variants. When we compared the NADPH in the variants to that in the parental cells, we found that the amount of the reduced form was similar (Table III). However, the total pool (NADPH + $\mathrm{NADP}^{+}$) was increased in all the variants compared to the WEHI7.2 cells. Neo2 and Neo3 cells were similar to the WEHI7.2 cells (data not shown). This indicated that there was more $\mathrm{NADP}^{+}$in the oxidative stress-resistant variants and the $\mathrm{NADP}^{+} / \mathrm{NADPH}$ ratio was altered. In most unstressed cells, $>90 \%$ of the NADP(H) pool is in the reduced or NADPH form (22), similar to what was observed in the WEHI7.2 cells. The $\mathrm{NADP}(\mathrm{H})$ pool was generally more oxidized in the oxidative stress-resistant variants.
G6PDH is the first and rate-limiting step in the pentose phosphate pathway, the major source of NADPH in the cell. Since the NADP $(\mathrm{H})$ pool may be affected by G6PDH activity, we measured the G6PDH activity in the parental cells and the variants. As shown in Table III, G6PDH activity was increased in the WEHI7.2 variants, which would be consistent with an increased demand for NADPH. Vector only-transfected cells were similar to the WEHI7.2 cells (data not shown).

Although not directly involved in the regulation of the redox environment, the $\mathrm{NAD}^{+} / \mathrm{NADH}$ redox couple acts as an electron sink (22). When we compared the NAD ${ }^{+}$and NADH in the variants and WEHI7.2 cells, we found no difference in the amount of $\mathrm{NAD}^{+}$or NADH (Table IV).

Phase 2 enzyme activity is increased in the catalaseoverexpressing WEHI7. 2 variants. A more oxidized redox environment, as measured by GSH/GSSG alterations, has been implicated in upregulating glutathione S-transferase (GST) and NQO1 $(23,25)$. These phase 2 enzymes detoxify chemotherapeutic drugs and metabolize oxidation products to decrease oxidative damage $(26,27)$. Increases in these enzymes have the potential to impact chemoresistance in lymphoma. As indicated in Table V, GST and NQO1 enzyme activities were increased in the WEHI7.2 variants compared to the WEHI7.2 parental cells. Neo2 cells had significantly higher NQO1 activity compared to WEHI7.2 cells, while Neo3 cells did not

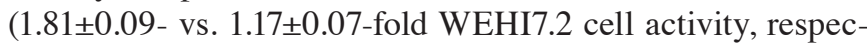
tively). GST activity in the $\mathrm{Neo} 2$ and $\mathrm{Neo} 3$ cells was similar to WEHI7.2 values (data not shown). Regression analysis of the enzyme activities with the GSSG/2GSH $\mathrm{E}_{\mathrm{h}}$ in the CAT2, 
Table IV. NAD + NADH redox couple in the WEHI7.2 cells and WEHI7.2 variants.

\begin{tabular}{lccc}
\hline $\begin{array}{l}\text { Cell } \\
\text { variant }\end{array}$ & $\begin{array}{c}\text { NADH } \\
\text { (pmol/mg prot) }\end{array}$ & $\begin{array}{c}\text { NAD(H) total } \\
(\mathrm{pmol} / \mathrm{mg} \text { prot })\end{array}$ & \% reduced \\
\hline WEHI7.2 & $152 \pm 14$ & $4,057 \pm 630$ & $3.8 \pm 0.9$ \\
CAT2 & $121 \pm 15$ & $4,356 \pm 595$ & $2.8 \pm 0.7^{\text {a }}$ \\
CAT38 & $141 \pm 12$ & $4,461 \pm 623$ & $3.2 \pm 0.7$ \\
200R & $104 \pm 15$ & $3,777 \pm 237$ & $2.8 \pm 0.6$ \\
\hline
\end{tabular}

Values represent the means \pm SEM $(n=6)$. This is a representative

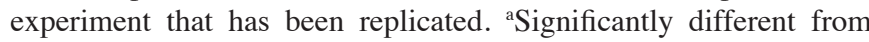
WEHI7.2 values $(\mathrm{p} \leq 0.05)$ after controlling for type I error.

Table V. Phase 2 enzymes in the WEHI7.2 cells and WEHI7.2 variants.

\begin{tabular}{lcc}
\hline $\begin{array}{l}\text { Cell } \\
\text { variant }\end{array}$ & $\begin{array}{c}\text { Glutathione S-transferase } \\
(\mu \text { moles/min/mg prot })\end{array}$ & $\begin{array}{c}\text { NAD(P)H:quinone } \\
\text { oxidoreductase } \\
(\mu \text { moles DPIP reduced } / \\
\text { min/mg prot })\end{array}$ \\
\hline WEHI7.2 & $55.28 \pm 3.94$ & $12.99 \pm 0.82$ \\
CAT2 & $133.00 \pm 8.21^{\mathrm{a}}$ & $42.46 \pm 1.02^{\mathrm{a}}$ \\
CAT38 & $80.71 \pm 1.17^{\mathrm{a}, \mathrm{b}}$ & $28.83 \pm 4.87^{\mathrm{a}, \mathrm{b}}$ \\
200R & $66.07 \pm 4.14$ & $23.08 \pm 1.85^{\mathrm{a}}$ \\
\hline
\end{tabular}

Values represent the means \pm SEM $(n=6)$. ${ }^{\text {SSignificantly different }}$ from WEHI7.2 values $(\mathrm{p} \leq 0.05)$ after controlling for type I error. ${ }^{\mathrm{b}} \mathrm{CAT} 38$ values are significantly different from CAT 2 values $(\mathrm{p} \leq 0.05)$.

CAT38 and 200R cells showed that GST and NQO1-specific activity was correlated with the $\mathrm{E}_{\mathrm{h}}(\mathrm{p}=0.0025$ and 0.0000746 , respectively). A further analysis of the GST isozymes showed that both the $\mu$ and $\pi$ isozymes were increased in the WEHI7.2 variants (Fig. 2). GST $\alpha$ was below the limits of detection on our immunoblots.

Increasing catalase does not alter intracellular ROS in unstressed cells. The elevated catalase and SOD activities in the WEHI7.2 variants have the potential to affect the amount of ROS in the cell by increasing the removal of $\mathrm{H}_{2} \mathrm{O}_{2}$ and $\mathrm{O}_{2}{ }^{-}$. We measured the basal ROS using the ROS-sensitive dye, DCFH-DA. ROS levels (DCF fluorescence) in the CAT2, CAT38, 200R and vector only-transfected cells were similar to those in the WEHI7.2 cells (Fig. 3). The lack of change in DCF fluorescence was not due to differential dye uptake, since all the values were corrected for the fluorescence of 5-(and-6)-carboxy-2'7'dichlorofluorescein diacetate (C-369; Molecular Probes), a dye that fluoresces in the cell independent of ROS production (28).

Enhanced anti-oxidant defenses result in oxidant resistance. Based on the primary anti-oxidant defense enzyme profile, we predicted that the WEHI7.2 variants would be more resistant

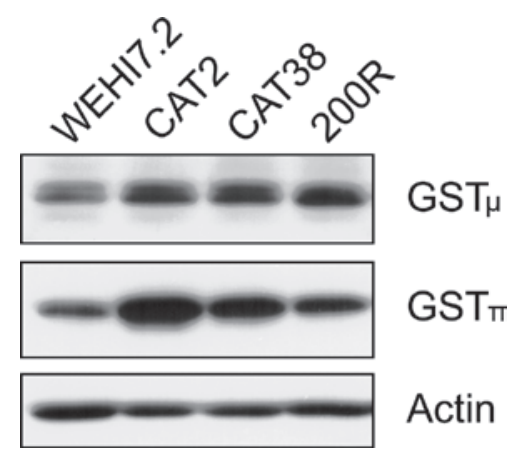

Figure 2. Immunoblotting of glutathione S-transferase $\mu$ and $\pi$ isoforms in the WEHI7.2 cells and WEHI7.2 variants. Cell variants are abbreviated as in the legend of Fig. 1. GST $\mu$ is the lower of the two bands. Actin is included as a loading control. This is a representative blot which has been replicated.

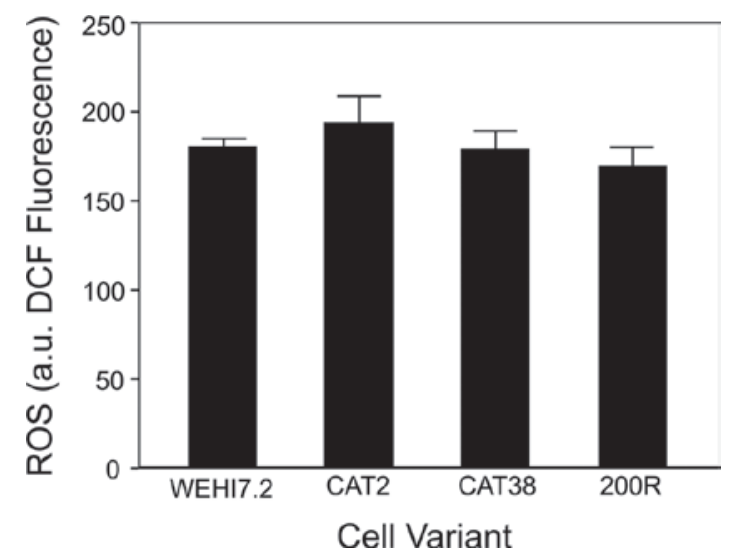

Figure 3. Comparison of intracellular ROS in the WEHI7.2 cells and WEHI7.2 variants. Values have been corrected for cDCFH dye uptake relative to WEHI7.2 cells. Values represent the means \pm SEM $(n=6)$. a.u., arbitrary fluorescence units.

to $\mathrm{H}_{2} \mathrm{O}_{2}$ and $\mathrm{O}_{2}{ }^{-}$. To test this prediction, we measured the sensitivity of the WEHI7.2 cells and the variants to a number of oxidants. In addition to $\mathrm{H}_{2} \mathrm{O}_{2}$, we compared the resistance to paraquat, which enters the cells and is metabolized to produce endogenous $\mathrm{O}_{2}^{--}$(29); 4-hydroxynonenol, a lipid peroxidation byproduct that reacts with and damages proteins and lipids (30); and tert-butyl hydroperoxide, which causes toxicity via lipid peroxidation and oxidation of thiols (31). As expected, elevated catalase activity (CAT2, CAT38 cells) increased the resistance to $\mathrm{H}_{2} \mathrm{O}_{2}$ (Table VI). The $\mathrm{EC}_{50}$ for $\mathrm{H}_{2} \mathrm{O}_{2}$ in the catalase transfectants was not as high as in the $200 \mathrm{R}$ cells that were selected for $\mathrm{H}_{2} \mathrm{O}_{2}$ resistance. All the variants were more resistant to paraquat suggesting an increased ability to metabolize $\mathrm{O}_{2}{ }^{-}$. The CAT38 and 200R cells were more resistant to 4-hydroxynonenol and the CAT2 cells more resistant to tert-butyl hydroperoxide. The vector only-transfectants had only two significant differences from the WEHI7.2 cells: i) $\mathrm{Neo} 3$ cells were $1.13 \pm 0.02$-fold more resistant to paraquat; and ii) $\mathrm{Neo} 2$ cells were $1.53 \pm 0.06$-fold more resistant to 4-hydroxynonenol.

Enhanced anti-oxidant defenses increase resistance to multiple lymphoma chemotherapeutics. The oxidative stressresistant variants showed increased resistance to $\mathrm{H}_{2} \mathrm{O}_{2}$ and 
Table VI. Oxidant sensitivity in the WEHI7.2 cells and WEHI7.2 variants as measured by EC $_{50}$ values.

\begin{tabular}{lcccc}
\hline Cell variant & $\mathrm{H}_{2} \mathrm{O}_{2}(\mu \mathrm{M})$ & Paraquat $(\mu \mathrm{M})$ & 4-hydroxynonenol $(\mu \mathrm{M})$ & Tert-butyl hydroperoxide $(\mu \mathrm{M})$ \\
\hline WEHI7.2 & $105.37 \pm 2.94$ & $32.73 \pm 6.68$ & $12.67 \pm 1.23$ & $0.939 \pm 0.045$ \\
CAT2 & $201.08 \pm 12.99^{\mathrm{a}}$ & $84.38 \pm 5.90^{\mathrm{a}}$ & $9.97 \pm 0.57$ & $1.433 \pm 0.062^{\mathrm{a}}$ \\
CAT38 & $348.58 \pm 4.48^{\mathrm{a}, \mathrm{b}}$ & $418.77 \pm 44.50^{\mathrm{a}, \mathrm{b}}$ & $16.90 \pm 1.58^{\mathrm{a}, \mathrm{b}}$ & $1.143 \pm 0.009^{\mathrm{b}}$ \\
200R & $1,049.26 \pm 9.83^{\mathrm{a}}$ & $77.00 \pm 8.96^{\mathrm{a}}$ & $20.33 \pm 0.83^{\mathrm{a}}$ & $1.098 \pm 0.068$ \\
\hline
\end{tabular}

Values represent the means \pm SEM (n=3-6). ${ }^{a}$ Significantly different from WEHI7.2 values ( $\left.\leq 0.05\right)$ after controlling for type I error. ${ }^{\text {b } C A T 38}$ values are significantly different from CAT2 values $(\mathrm{p} \leq 0.05)$.

Table VII. Sensitivity of the WEHI7.2 cells and WEHI7.2 variants to lymphoma chemotherapeutics.

\begin{tabular}{|c|c|c|c|c|c|c|}
\hline $\begin{array}{l}\text { Cell } \\
\text { variant }\end{array}$ & $\begin{array}{l}\text { Cyclophosphamide } \\
\mathrm{EC}_{50}(\mathrm{mM})^{\mathrm{a}}\end{array}$ & $\begin{array}{l}\text { Doxorubicin } \\
\mathrm{EC}_{50}(\mathrm{nM})^{\mathrm{a}}\end{array}$ & $\begin{array}{l}\text { Doxorubicin } \\
\mathrm{EC}_{90}(\mathrm{nM})^{\mathrm{a}}\end{array}$ & $\begin{array}{l}\text { Vincristine } \\
\mathrm{EC}_{50}(\mathrm{nM})^{\mathrm{a}}\end{array}$ & $\begin{array}{l}\text { Vincristine } \\
\mathrm{EC}_{90}(\mathrm{nM})^{\mathrm{a}}\end{array}$ & $\begin{array}{l}\text { Dexamethasone } \\
\text { (apoptosis \%) }^{\mathrm{b}}\end{array}$ \\
\hline WEHI7.2 & $1.82 \pm 0.03$ & $8.60 \pm 0.58$ & $23.74 \pm 0.65$ & $2.37 \pm 0.17$ & $4.26 \pm 0.34$ & $21.73 \pm 1.03$ \\
\hline CAT2 & $9.04 \pm 0.39^{c}$ & $13.80 \pm 0.96^{\mathrm{c}}$ & N.D. & $6.04 \pm 0.42^{\mathrm{c}}$ & $10.75 \pm 1.04^{\mathrm{c}}$ & $0.29 \pm 0.09^{c}$ \\
\hline CAT38 & $7.69 \pm 0.07^{c}$ & $27.28 \pm 2.93^{\mathrm{c}, \mathrm{d}}$ & $37.19 \pm 1.62^{\mathrm{c}}$ & $6.06 \pm 0.79^{c}$ & $24.45 \pm 0.13^{\mathrm{c}, \mathrm{d}}$ & $1.08 \pm 0.45^{\mathrm{c}}$ \\
\hline 200R & $5.71 \pm 0.18^{c}$ & $11.40 \pm 1.11$ & $28.66 \pm 0.72^{c}$ & $9.01 \pm 3.90$ & $48.43 \pm 3.53^{c}$ & $10.75 \pm 0.61^{c}$ \\
\hline
\end{tabular}

${ }^{\mathrm{a}}$ Values represent the means $\pm \operatorname{SEM}(\mathrm{n} \geq 3)$. ${ }^{\mathrm{b}}$ Values are the mean percentage of apoptosis after a $24-\mathrm{h}$ treatment with $1 \mu \mathrm{M}$ dexamethasone corrected for percentage of apoptosis in vehicle-treated cells $(n=9)$. N.D., not determined. ${ }^{c}$ Significantly different from WEHI7.2 values $(\mathrm{p} \leq 0.05)$ after controlling for type I error. ${ }^{\mathrm{d}} \mathrm{CAT} 38$ values are significantly different from CAT2 values $(\mathrm{p} \leq 0.05)$.

$\mathrm{O}_{2}{ }^{\bullet-}$ concomitant with increased GST activity. Based on this profile, we predicted that the oxidative stress-resistant cells would be resistant to lymphoma drugs that depend on ROS generation for cell death or are detoxified via GST-dependent mechanisms.

To assess the relative resistance of the WEHI7.2 variants and WEHI7.2 parental cells to lymphoma chemotherapeutics, we measured the response to cyclophosphamide, vincristine, doxorubicin and glucocorticoids, all components of standard lymphoma therapy (32). Previous studies indicate that glucocorticoids and doxorubicin increase ROS in lymphoid cells $(15,33)$; doxorubicin, vincristine and cyclophosphamide are all detoxified by GST-dependent mechanisms (34-38). As shown by the $\mathrm{EC}_{50}$ measurements in Table VII, the CAT2 and CAT38 cells were more resistant to cyclophosphamide, doxorubicin and vincristine than the WEHI7.2 cells $(\mathrm{p} \leq 0.05)$. The 200R cells were more resistant than the WEHI7.2 cells to cyclophosphamide, as indicated by the higher $\mathrm{EC}_{50}$. Using the $\mathrm{EC}_{50}$ as a measure, the $200 \mathrm{R}$ cells were not more resistant to doxorubicin or vincristine. However, the $\mathrm{EC}_{90}$ measurements for both doxorubicin and vincristine indicated that the 200R cells were more resistant to both these drugs than the WEHI7.2 cells ( $\mathrm{p} \leq 0.05)$. To assess dexamethasone resistance, we tested for a delay or prevention of apoptosis after treatment of the cells with $1 \mu \mathrm{M}$ dexamethasone, the concentration of dexamethasone required to saturate the receptors $(8,9)$. As shown in Table VII, the variants had decreased apoptosis $24 \mathrm{~h}$ after the addition of dexamethasone indicating a decreased dexamethasone sensitivity. The vector only-transfected cells were not more resistant to any of the chemotherapeutics (data not shown). These data indicate that increasing the oxidative stress resistance in the WEHI7.2 cells resulted in chemoresistance to multiple lymphoma chemotherapeutic drugs.

\section{Discussion}

The data presented here suggest that lymphomas that are derived from sites of chronic inflammation acquire a chemoresistant phenotype resulting from enhanced anti-oxidant defenses. The variants with increased catalase, via transfection or selecting for $\mathrm{H}_{2} \mathrm{O}_{2}$ resistance, had widespread resistance to the chemotherapy agents we tested. One possible explanation is that increased $\mathrm{H}_{2} \mathrm{O}_{2}$ removal is universally protective. However, none of the variants were resistant to all of the oxidants we tested. This suggests that increased $\mathrm{H}_{2} \mathrm{O}_{2}$ removal is unlikely to be the sole mechanism of resistance. A second possibility is that an increase in catalase upregulates pathways responsible for a more generalized drug resistance. We did not see an increase in anti-apoptotic Bcl-2 family members or a decrease in pro-apoptotic Bcl-2 family members that could explain a generalized drug resistant phenotype (unpublished data). However, in addition to the increased catalase activity, the variants had an altered redox environment with concomitant increases in SOD activity and the phase 2 enzymes GST and NQO1. In other model systems, these enzymes cause drug resistance (26). Our data indicate that altering catalase modulates multiple redox responsive pathways, including ones that detoxify drugs by $\mathrm{H}_{2} \mathrm{O}_{2}$-independent mechanisms. This could account for a more generalized resistance than would be predicted by $\mathrm{H}_{2} \mathrm{O}_{2}$ removal alone.

For the chemotherapeutics we tested, both an increase in the ability to detoxify ROS directly and elevated phase 2 
enzymes likely play a role in resistance. Direct removal of ROS may play a role in the resistance to glucocorticoids and doxorubicin, since treatment with each of these agents increases ROS production $(15,33)$. There is considerable evidence that the addition of chemical or enzymatic anti-oxidants, or preventing ROS generation after glucocorticoid treatment, protects lymphoid cells from glucocorticoid-induced apoptosis $(9,15,39)$. Doxorubicin treatment increases intracellular ROS in lymphoid cells (33), most likely due to its ability to redox cycle in the cell to produce superoxide (40). However, doxorubicin has multiple cellular effects (41). Although the poisoning of topoisomerase II is often considered the most clinically relevant, the relative contributions of individual doxorubicin effects, including ROS generation, is not clear (41-43). Direct ROS removal is unlikely to play a role in the resistance to cyclophosphamide, a DNA strand-crosslinking agent (44), or vincristine, a microtubule polymerization inhibitor $(33,45)$. Treatment of lymphoid cells with these drugs has not been connected with an increase in $\operatorname{ROS}(33,44)$.

The increase in GST $\mu$ and $\pi$ in the WEHI7.2 variants likely contributed to the observed chemoresistant phenotype. These GST isozymes detoxify neoplastic agents by conjugating GSH to them to facilitate their export $(26,27)$. Although GSH was lower in the CAT2, CAT38 and 200R cells than in the WEHI7.2 parental cells, there may still have been enough GSH present for these enzymes to function. Increases in GST $\mu$ and/or $\pi$ have been shown to decrease the toxicity of cyclophosphamide $(34,35)$, doxorubicin $(36,37)$ and vincristine $(36,38)$. GSTs also inhibit apoptosis due to multiple agents via regulation of the MAP kinase pathway. GST $\pi$ binds to and inhibits the activity of c-Jun N-terminal kinase (JNK1) $(46,47)$. JNK1 activation has been implicated in the cytotoxicity mechanism of doxorubicin and vincristine (47). Increases in GST $\mu$ also inhibit activation of p38-MAPK and Bim which are important for glucocorticoid-induced apoptosis (48).

The $\mathrm{H}_{2} \mathrm{O}_{2}$-resistant $200 \mathrm{R}$ cells most closely model a cell population that would be found at the site of chronic infection/inflammation, with the catalase-overexpressing clones useful as proof of principle. A critical examination of the data suggests that the 200R cells appear less resistant to many drugs than the other WEHI7.2 variants. This is deceptive because for most of the drugs and oxidants there is a small population of cells that shows much greater resistance. We have noted this phenomenon in response to other agents $(8,14)$. Thus, an $\mathrm{EC}_{50}$ measurement may not always reflect this response. The vincristine response is a good example of this phenomenon. The $\mathrm{EC}_{50}$ for the 200R cells did not differ much from that in the WEHI7. 2 cells. However, the $\mathrm{EC}_{90}$ was very high compared to both the $\mathrm{EC}_{50}$ in the $200 \mathrm{R}$ cells and the $\mathrm{EC}_{90}$ in the WEHI7.2 cells. Drug treatment in the clinic may select for the resistant population, posing a significant barrier to successful treatment.

Taken together, these data indicate that upregulation of anti-oxidant defenses by chronic ROS exposure or by transfection results in cells with a chemoresistant phenotype. Our data show that modulation of one anti-oxidant defense enzyme or selection for oxidant resistance causes coordinate changes in the web of redox-sensitive molecules. These data serve as a cautionary tale for studies that make the assumption that if catalase is increased by transfection, and the resultant cells are resistant to a particular drug, the mechanism of cell death must depend on hydrogen peroxide. This study suggests one mechanism by which the development of oxidative stress resistance contributes to a general chemoresistant phenotype. Multiple mechanisms probably exist. Although we do not have an explanation for the mechanism by which increased $\mathrm{H}_{2} \mathrm{O}_{2}$ resistance (or increased catalase) causes all the redox alterations we observed in the WEHI7.2 variants, the resulting chemoresistant phenotype has potential clinical consequences. Successful treatment of lymphomas arising at the site of chronic inflammation must take into account the multiple alterations likely to have occurred in the lymphoma cells.

\section{Acknowledgements}

The authors thank Krispy Sofkie and Mandy Wilson for the technical assistance; Debbie Sakeistewa for the flow cytometry expertise; Margareta Berggren for the peroxiredoxin cDNAs; David Stringer for the use of critical equipment; and Dr Melba Jaramillo for the critical discussion of the manuscript. Funding for this study comes from the National Cancer Institute (CA 71768) to M.M.B., (CA 17094) to R.T.D. and (CA 43894, CA 106677, CA 99469) to E.L.J.; and The Department of Pathology (University of Arizona) to M.M.B. and M.E.T.. M.E.T. was partially supported by a T-32 traineeship from the N.C.I. (CA 09213) and E.L.J. was partially supported by CA 27502. Portions of this study were supported by the Arizona Cancer Center Core grant (CA 23074) and the Southwest Environmental Health Sciences Center Core grant (ES 06694).

\section{References}

1. Tavani A, La Vecchia C, Franceschi S, Serraino D and Carbone A: Medical history and risk of Hodgkin's and nonHodgkin's lymphomas. Eur J Cancer Prev 9: 59-64, 2000.

2. Jaffe ES, Harris NL, Stein H and Vardiman JW: World Health Organization Classification of Tumours: Pathology and Genetics of Tumours of Haematopoietic and Lymphoid Tissues. IARC Press, Lyon, 2001

3. Young LS and Rickinson AB: Epstein-Barr virus: 40 years on. Nat Rev Cancer 4: 757-768, 2004.

4. Ramos-Casals M, De Vita S and Tzioufas AG: Hepatitis C virus, Sjogren's syndrome and B-cell lymphoma: linking infection, autoimmunity and cancer. Autoimmun Rev 4: 8-15, 2005.

5. Gualandi G, Giselico L, Carloni M, Palitti F, Mosesso P and Alfonsi AM: Enhancement of genetic instability in human $\mathrm{B}$ cells by Epstein-Barr virus latent infection. Mutagenesis 16: 203-208, 2001.

6. Spitz DR, Li GC, McCormick ML, Sun Y and Oberley LW: Stable $\mathrm{H}_{2} \mathrm{O}_{2}$-resistant variants of Chinese hamster fibroblasts demonstrate increases in catalase activity. Radiat Res 114: 114-124, 1988.

7. Cantoni O, Guidarelli A, Sestili P, Mannello F, Gazzanelli G and Cattabeni F: Development and characterization of hydrogen peroxide-resistant Chinese hamster ovary cell variants. I. Relationship between catalase activity and the induction/stability of the oxidant-resistant phenotype. Biochem Pharmacol 45: 2251-2257, 1993.

8. Tome ME and Briehl MM: Thymocytes selected for resistance to hydrogen peroxide show altered antioxidant enzyme profiles and resistance to dexamethasone-induced apoptosis. Cell Death Differ 8: 953-961, 2001

9. Tome ME, Baker AF, Powis G, Payne CM and Briehl MM: Catalase-overexpressing thymocytes are resistant to glucocorticoid-induced apoptosis and exhibit increased net tumor growth. Cancer Res 61: 2766-2773, 2001.

10. Harris AW, Bankhurst AD, Mason S and Warner NL: Differentiated functions expressed by cultured mouse lymphoma cells. II. Theta antigen, surface immunoglobulin and a receptor for antibody on cells of a thymoma cell line. J Immunol 110: 431-438, 1973. 
11. Carlberg I and Mannervik B: Glutathione reductase. Methods Enzymol 113: 484-490, 1985.

12. Ernster L: DT diaphorase. Methods Enzymol 10: 309-317, 1967.

13. Tome ME, Johnson DBF, Samulitis BK, Dorr RT and Briehl MM Glucose 6-phosphate dehydrogenase overexpression models glucose deprivation and sensitizes lymphoma cells to apoptosis. Antioxid Redox Signal 8: 1315-1327, 2006.

14. Efferth T, Briehl MM and Tome ME: Role of antioxidant genes for the activity of artesunate against tumor cells. Int J Oncol 23 : $1231-1235,2003$

15. Tome ME, Jaramillo MC and Briehl MM: Hydrogen peroxide signaling is required for glucocorticoid-induced apoptosis in lymphoma cells. Free Radic Biol Med 51: 2048-2059, 2011.

16. Jones DP, Carlson JL, Samiec PS, Sternberg P Jr, Mody VC Jr, Reed RL and Brown LA: Glutathione measurement in human plasma. Evaluation of sample collection, storage and derivatization conditions for analysis of dansyl derivatives by HPLC. Clin Chim Acta 275: 175-184, 1998.

17. Jacobson EL and Jacobson MK: Tissue NAD as a biochemical measure of niacin status in humans. Methods Enzymol 280 221-230, 1997

18. Jones DP: Redox potential of GSH/GSSG couple: assay and biological significance. Methods Enzymol 348: 93-112, 2002.

19. Li JJ, Oberley LW, St Clair DK, Ridnour LA and Oberley TD: Phenotypic changes induced in human breast cancer cells by overexpression of manganese-containing superoxide dismutase. Oncogene 10: 1989-2000, 1995.

20. Moore DS and McCabe GP: Introduction to the Practice of Statistics. 4th edition. W.H. Freeman \& Co., New York, 2003.

21. Myers JL and Well AD: Research Design and Statistical Analysis. 2nd edition. Lawrence Erlbaum Associates, Mahwah, NJ, 2003.

22. Schafer FQ and Buettner GR: Redox environment of the cell as viewed through the redox state of the glutathione disulfide/ glutathione couple. Free Radic Biol Med 30: 1191-1212, 2001.

23. Kirlin WG, Cai J, Thompson SA, Diaz D, Kavanagh TJ and Jones DP: Glutathione redox potential in response to differentiation and enzyme inducers. Free Radic Biol Med 27: 1208-1218, 1999

24. Kirkman HN and Gaetani GF: Catalase: a tetrameric enzyme with four tightly bound molecules of NADPH. Proc Natl Acad Sci USA 81: 4343-4347, 1984.

25. Go YM, Gipp JJ, Mulcahy RT and Jones DP: $\mathrm{H}_{2} \mathrm{O}_{2}$-dependent activation of GCLC-ARE4 reporter occurs by mitogen-activated protein kinase pathways without oxidation of cellular glutathione or thioredoxin-1. J Biol Chem 279: 5837-5845, 2004.

26. Talalay P: Chemoprotection against cancer by induction of phase 2 enzymes. Biofactors 12: 5-11, 2000.

27. Hayes JD and Pulford DJ: The glutathione S-transferase supergene family: regulation of GST and the contribution of the isoenzymes to cancer chemoprotection and drug resistance. Crit Rev Biochem Mol Biol 30: 445-600, 1995.

28. Ahmad IM, Aykin-Burns N, Sim JE, et al: Mitochondrial $\mathrm{O}_{2}{ }^{-}$ and $\mathrm{H}_{2} \mathrm{O}_{2}$ mediate glucose deprivation-induced stress in human cancer cells. J Biol Chem 280: 4254-4263, 2005.

29. Krall J, Bagley AC, Mullenbach GT, Hallewell RA and Lynch RE: Superoxide mediates the toxicity of paraquat for cultured mammalian cells. J Biol Chem 263: 1910-1914, 1988.

30. Esterbauer H, Schaur RJ and Zollner H: Chemistry and biochemistry of 4-hydroxynonenal, malonaldehyde and related aldehydes. Free Radic Biol Med 11: 81-128, 1991

31. Jewell SA, Di Monte D, Richelmi P, Bellomo G and Orrenius $S$ : tert-Butylhydroperoxide-induced toxicity in isolated hepatocytes: contribution of thiol oxidation and lipid peroxidation. J Biochem Toxicol 1: 13-22, 1986
32. Perry MC, Anderson CM, Dorr VJ and Wilkes JD: Companion Handbook to the Chemotherapy Source Book. Lippincott, Williams \& Wilkins, New York, 1999.

33. Kamio T, Toki T, Kanezaki R, et al: B-cell-specific transcription factor BACH2 modifies the cytotoxic effects of anticancer drugs. Blood 102: 3317-3322, 2003.

34. Matsunaga T, Sakamaki S, Kuga T, et al: GST-pi gene-transduced hematopoietic progenitor cell transplantation overcomes the bone marrow toxicity of cyclophosphamide in mice. Hum Gene Ther 11: 1671-1681, 2000.

35. McGown AT and Fox BW: A proposed mechanism of resistance to cyclophosphamide and phosphoramide mustard in a Yoshida cell line in vitro. Cancer Chemother Pharmacol 17: 223-226, 1986.

36. O'Brien M, Kruh GD and Tew KD: The influence of coordinate overexpression of glutathione phase II detoxification gene products on drug resistance. J Pharmacol Exp Ther 294: 480-487, 2000.

37. Harbottle A, Daly AK, Atherton K and Campbell FC: Role of glutathione S-transferase P1, P-glycoprotein and multidrug resistance-associated protein 1 in acquired doxorubicin resistance. Int J Cancer 92: 777-783, 2001.

38. Depeille P, Cuq P, Mary S, Passagne I, Evrard A, Cupissol D and Vian L: Glutathione S-transferase M1 and multidrug resistance protein 1 act in synergy to protect melanoma cells from vincristine effects. Mol Pharmacol 65: 897-905, 2004

39. Tonomura N, McLaughlin K, Grimm L, Goldsby RA and Osborne BA: Glucocorticoid-induced apoptosis of thymocytes: requirement of proteasome-dependent mitochondrial activity. J Immunol 170: 2469-2478, 2003.

40. Davies KJ: Oxidative stress: the paradox of aerobic life. Biochem Soc Symp 61: 1-31, 1995.

41. Gewirtz DA: A critical evaluation of the mechanisms of action proposed for the antitumor effects of the anthracycline antibiotics adriamycin and daunorubicin. Biochem Pharmacol 57: 727-741, 1999.

42. Trevino AV, Woynarowska BA, Herman TS, Priebe W and Woynarowski JM: Enhanced topoisomerase II targeting by annamycin and related 4-demethoxy anthracycline analogues. Mol Cancer Ther 3: 1403-1410, 2004.

43. Shacter E, Williams JA, Hinson RM, Senturker S and Lee YJ: Oxidative stress interferes with cancer chemotherapy: inhibition of lymphoma cell apoptosis and phagocytosis. Blood 96: 307-313, 2000.

44. Murata M, Suzuki T, Midorikawa K, Oikawa S and Kawanishi S Oxidative DNA damage induced by a hydroperoxide derivative of cyclophosphamide. Free Radic Biol Med 37: 793-802, 2004.

45. Huang Y, Fang Y, Wu J, Dziadyk JM, Zhu X, Sui M and Fan W: Regulation of Vinca alkaloid-induced apoptosis by NF-kappaB/ IkappaB pathway in human tumor cells. Mol Cancer Ther 3: 271-277, 2004

46. Adler V, Yin Z, Fuchs SY, et al: Regulation of JNK signaling by GSTp. EMBO J 18: 1321-1334, 1999.

47. Townsend DM and Tew KD: The role of glutathione-S-transferase in anti-cancer drug resistance. Oncogene 22: 7369-7375, 2003.

48. Hosono N, Kishi S, Iho S, et al: Glutathione S-transferase M1 inhibits dexamethasone-induced apoptosis in association with the suppression of Bim through dual mechanisms in a lymphoblastic leukemia cell line. Cancer Sci 101: 767-773, 2010. 